\title{
Legal Aspects of Industrial Enterprise Security in Mining Region
}

\author{
Valery Znikin ${ }^{1, *}$, and Eugeny Zharikov ${ }^{2}$ \\ ${ }^{1}$ Kemerovo State University, 650000, 6 Krasnaya st., Kemerovo, Russian Federation \\ ${ }^{2}$ National Research Tomsk State University, 634050, 36 Lenina ave, Tomsk, Russia
}

\begin{abstract}
To be in safety means to be in such secure conditions that are controlled in the firm's activity. The risk in these cases is always manageable and predictable. So, studying, explanation and estimation of the entity's environment that is under secure must be an unconditional rule for the security service. It comes from everyday studying, explanation and estimation of its forces and means, as well as, the means and forces of the competitors, partners, raiders, criminal structures in a specific developing situation of the secured entity's environment
\end{abstract}

\section{Introduction}

The modern enterprise can be regarded as a field of legal and economic risks. The main idea of this article is correlated with numerous publications on the security's service role in the enterprise's activity: the identifying of the direct correlations between the facts of legal and economic violations in the business entity and the grounding of the security service level at this enterprise. We consider the concept "the security service readiness" from the point of justifying the importance of non-stop training and improving the specialists' skills in this field, whose activities, surely, must be "the tool" of the corporate security in the enterprise.

\section{Materials and Methods}

Learning through the whole life is the axiom. The illustration of this one can be the life experience of many well-known people. "Learning is a like rolling against the current. As you stop it the current just drifts you back." That is the quote of Benjamin Britten (19131976), a composer from a small English town of Aldboroug, author of the operas "Peter Grimes", "Albert Herring", "The Turn of the Screw", "The Midsummer Night's Dream", and works about children and for children. It is hardly ever possible to mention more convincingly and clearly than the children's composer would express it. Learning through your whole is a fundamental truth that does not need proofs. "A talent that does not increase day by day, decreases every day", the Chinese proverb says. Benjamin Franklin, American writer and politician (1706 - 1790) noted: "Investments in knowledge give the greatest profit".

\footnotetext{
${ }^{*}$ Corresponding author: tma.geolog@,kuzstu.ru
} 
The key word in the notion of "professional development" is qualification. We pre-lay the condition that we are to train a person who already has special knowledge in any professional activity. Undoubtedly, in our context that is the sphere of business security.

\section{Results and Discussion}

The head of the security service of the economic entity plays an important role in the formation of a steady work of an enterprise or a firm timely preventing wrongful encroachments or criminal and technogenic activities. His job is characterized with a considerable spectrum of communication acts, trust, special knowledge and skills, and significantly differs from other security services.

It is logical that the head of the security service must be a person who already possesses the skills, sufficient experience and talent of an expert in human diplomacy. And this person needs to be taught such volume of knowledge which will enrich his professional activity.

Unfortunately, today's programs and trainings are not always able to present such a multiplicity. Moreover, the current training curricula sometimes do not have sufficient methodological level. We come to this conclusion in the framework of the analysis of the curricula for the professional development of the heads of security services.

We will try to present our conception by means of concrete proposals.

The conceptual framework of corporate security will help to describe these aspects. It is necessary to begin with the conceptual number corporate security basis. It is important to realize that the set of business entity's living conditions which it has mastered (comprehended, acquired, created) during the self-realization, and which he thus can control, is the security on an entity and security of his activity.

We should make an important conclusion: security is not a condition of entity's interests; security is not a condition of anybody's interests. Security is the living conditions of managing an entity which it controls.

It is clear that to be in secure means to be in safe conditions, that is such conditions when an entity is able to control the activity and self-realization. In our opinion, it will be reasonable to appeal to the book by Benjamin Gilad "Early Warning" [1].

It should be mentioned that there are no other books on the subject of "early warning". In the original, the book is called: "Early Warning. Using competitive intelligence to anticipate market shifts, control risk, and create powerful strategies." The readers who expect from the book sentimental stories about corporate espionage will be disappointed.

What is this "early warning"? According to Gilad' interpretation, an early warning system should help companies " to recognize the threats at an early stage until it has become a full-blown crisis, and identify early signs of enabling opportunities earlier than others do "[1, p.14]. The essence of the system of early warning of undesirable consequences in business is the implementation of systemic consolidation of strategic planning, intelligence and optimal management decision-action.

Today there are representatives of all types of private business, including such as competitive intelligence and security audit among market participants. The subject of the study of these professionals is information, and the result of consulting and research work is information that allows timely detect existing threats to the business and take adequate secure measures [2]. So, you can be safe only when you are in controlled conditions. This is especially true for those entrepreneurs who, for various reasons, do not currently have their own specialists in this activity.

Competitive intelligence as one of the forms of search and cognitive activity is a segment of the sphere of professional detective activity's interests. Analytical conclusions 
of representatives of competitive intelligence can be used both for making tactical decisions, and for developing strategic directions for the development of the company [3 - 5].

Let us clarify the most important conditions for the entity of security. First of all, it is the resources required to meet the need for self-realization of the entity (in survival, existence and development). The resources are limited, and needs are growing due to the development and self-realization of the economic entity, it is impossible to fully satisfy these needs [6;7].

The conditions for the existence of a security entity in market conditions are also competitors. To gain an advantage over competitors, create additional income and prevent withdrawal from business, the competent use of modern methods used in the fight against the leakage of intellectual property. Therefore, in today's competitive struggle, the important thing is the knowledge of the intentions of competitors, the study of the main trends in business and political life, the analysis of entrepreneurial risks and other factors affecting business activity [8]. Competitive intelligence, unlike industrial espionage, is within the framework of the legal activity. The results are obtained through analytical processing of a great number of various open information resources $[9 ; 10]$.

An inevitable difficulty is the presence of other economic entity that has its own vital interests and requirements. It makes the situation more complicated because of entity's aspiration to take use and control resources. When there is opportunity to use off-side resources, requirements of two and more entities are crossed during business activities, a conflict concerning resources appears. That is the competition. Thus, security of one entity depends on security of another. The conflict of interests of economic entities is manifested not only in the "company / company" category, but in form of "company / person one.

It is possible to formulate the idea of security: to ensure our own security it is necessary to fully identify competitors (the sources of threats, interests, resource requirements, as well as the availability, quantity and quality of resources already controlled by a competitor or available on the market in any kinds). It means that information is a tool, which makes such direct and reverse connections between entities in direct environment, when influence of one entity does not cause any negative changes in its conditions.

In fact, the combination of these factors allows us to assert that business (competitive) intelligence and business counterintelligence are regarded as tools and means of corporate security of the enterprise.

These factors give a background to present a truncated business security model [11]:

- It is application of the situational approach in security activity providing possible variants of situations on security entity

- The process of collecting, accumulating, structuring, analyzing data about the internal and external environment of the company; $\rightarrow$ transfer information to the top management for the adoption of a timely (preemptive) optimal solution for risk management, changes in the security system; $\rightarrow$ taking appropriate measures to meet future customer demands and maintain the company's profitability.

- Control over the state of the interests and conditions for the existence of competition entities, partnerships, raider companies and possible criminal groups.

- Finding and attracting additional (voluntary, interested or dependent) information sources in the security entity.

- Introduction of intellectual protection elements, taking into account professional cover; $\rightarrow$ receiving (collecting and retrieving) proactive information about threats to the security entity; $\rightarrow$ implementation of solutions on a pre-worked out scheme.

The corporate security model of any firm is easy to express. At the same time, it is possible to be involved in a discussion with those who believe that threats arise mainly from outside. Elements of risk factors are always manifested in two spheres, and they can be detected, as a rule, not only outside the company, but actually in itself. 
Below, in Fig. 1 presents the author's model of correlation and interrelation of business entities [12]. Graphic components of the model:

- "Triangle" of problems of business entities;

- "Circle" of interests of persons involved in business;

- "Square" of interacting persons.

The angles of the "Triangle" we define: I. What happens? II. How can events develop? III. Who is involved?

The "Circle" of interests is the definition of the choice of competitors: to penetrate into other people's interests or to protect oneself.

"Square" of persons is a characteristic of persons interacting in the process of business: 1. The owner; 2. The top manager; 3. The owner of security; 4. Acting participants, significantly affecting all processes, but not formally responsible for the results of making any decision in the company.

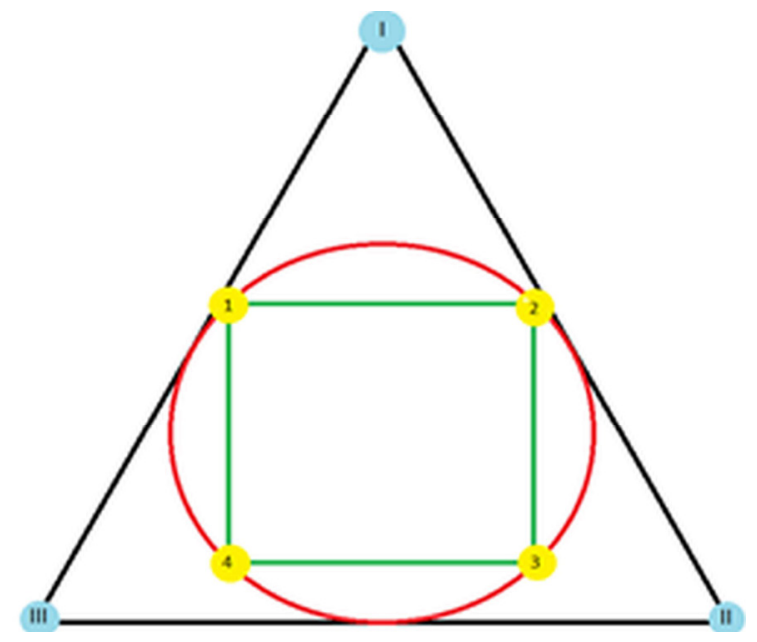

Fig. 1. Model of correlation and interrelation of business entities.

We completely agree with the method of Harvard University professor Michael Porter, convinced that any company needs a good competitive intelligence - information about the competitive environment and competitors [13]. In his conception, the "five forces" model that governs competition is used:

- The threat from existing competitors.

- The threat of the emergence of substitute goods or substitute services that are competitive in terms of price.

- The threat of new or potential competitors.

- The threat from suppliers of raw materials and components.

- The threat from consumers of goods and services.

However, there are always informational positions of attacking people in the team. The information of these sources can be obtained by involving staff representatives in the information cooperation. Information positions can be initiated by the employees of the firm. Do not really like it? Let us refer again to Benjamin Gilad's book "Early Warning": "The early warning process does not give managers what they want to know, but warns them about what they need to know" [1, p. 186]. An early warning group is necessary so that the employer does not become a hostage of his illusory notion of reality, because flatterers are not able to "warn" by nature.

In fact, the threat of corporate security does occur from within. This is a very important discovery for a proprietor. The facts of larceny, swindle, disclosure of commercial secrets 
and other information, squabble, gossip, scheming and other deliberate actions of the personnel cause a tangible damage to the business interests.

Spoilers and "rascals" in a company always exist. So, there are four vivid questions: 1) Who are those persons in corporate company? 2) What is the cause of their tricks? 4) Is there a real effective mechanism to counteract to such infection and how it works?

We will try to answer the first question. Of course, these are the employees who surround us. And the employees belong to the owner himself, as well as top managers, managers, maintenance personnel, drivers, security guards, etc. Among them we can single out situational partners as relatives, friends, co-founders, enemies, envious persons, offended and punished, previously brought to criminal responsibility, potential infringers of labor discipline suffering from lack of money, and willing to start their own business at your expense, etc.

The second question demands a laconic answer. This is greed, envy, revenge, slovenliness, debts, passion and other defects which finally cause damage to company's interests.

The answer to the third and the fourth questions demands reasoning. A real effective mechanism for counteracting such acts in the enterprise is not easy. The daily monitoring of entity's conditions and its environment is necessary.

If the company has regular corporate security, the problems of watching entity's conditions and in its environment, teaching them the skills and receptions of protections against negative displays of "well-wishers" and their consequences are carried out systematically. These entire things are written in documents on throughput modes inside an entity and company's information protection. Non-observance of positions written in a document leads to typical kinds of abusing and offences of company's staff:

- wastage of working time;

- using of corporate property for personal purposes;

- theft of inventory, expendable material, petroleum products, etc.;

- collusion of suppliers, customers in pricing issues;

- granting of favorable conditions for compensation ("payoffs");

- accounting's deformation and appropriation;

- sale of the corporate estate without permission;

- payment to figureheads and other frauds with money resources;

- theft of personal property from employees (also by extraneous persons).

The writing and approval of this document is preceded by hard work to study, understand and evaluate the forces and resources of the company's corporate security.

The provisions of the internal security regime and the protection regime are mandatory for the strict execution by all members of the team, including the owner and top managers. Otherwise, this document will practically be null and void. The principle "Do as I do!" in corporate security is a sacred rule. The proprietor in corporate security is the main "rattrapper." If he does not "catch" rats, nobody will "do it, and, as a result, - there will only be a visibility of corporate security.

\section{Conclusion}

Systematic personnel training by security experts will always bear fruit, if this training is not formal. Knowledge of the signs and mechanisms inside corporate and external threats to the interests of the company is real means of obtaining proactive information that allows the owner and management to make the optimal management decision on preventive maintenance, prevention and suppression of negative consequences.

To be in safety means to be in such conditions that are controlled in the firm's activity. The risk in these cases is always manageable and predictable. The study, explanation and 
assessment of entity's environment that is under secure must be an unconditional rule for a security director. It comes from everyday study, clarification and estimation of the forces and means, as well as the forces and means of competitors, partners, raiders, criminal structures in a specific developing situation of an entity's environment that is under secure.

\section{References}

1. B. Gilad Early, Warning. Using Competitire Intelligence to Anticipate Market Shifts Control Risk and Create Powerful Strategies (AMACOM, London, 2003)

2. N. R. Bottom, R.R.J Gallati, Industrial Espionage: Intelligence Techniques and Countermeasures. (Butterworth Publishers, New York, 1984)

3. K. Melton, C. Piligian, Office Espionage (Alpina non-fiction, Moscow, 2013)

4. J. Wilson, D. Brucksbenk, Security Manual (Uniti-Dana, Moscow, 2003)

5. S. Kamp, Legalnyy promyshlennyy shpionazh: Benmarking biznes- protsessov: tekhnologii poiska $i$ vnedreniye luchshikh metodov raboty vashikh konkurentov (Balans-Klub, Dnepropetrovsk, 2004)

6. B. Parad, Commercial Espionage. 79 Ways to Get the Secrets (Alpina, Moscow, 2005)

7. E.C. Prescott, International Economic Review, 25, 322 (1984)

8. C. Khant, V. Zartarian, Razvedka na sluzhbe vashego predpriyatiya (Ukrzkordonvizaservis, Kiev, 1992)

9. Hemng Academy of Competitive Intelligence (Cambridge, USA, 1995)

10. V. Platt, Dobyvaniye. analiz i obrabotka strategicheskikh razvedyvatelnykh dannykh (Distribyushn, Moscow, 2006)

11. V. K. Znikin, Konkurentnoye pravo, 2, 100 (2011)

12. V. K. Znikin, Professional Security Training and Qualification at Manager Level and Above (BFRD, London, 2010)

13. M. E. Porter, International Competition (Logan, Chicago, 1993) 